DOI https://doi.org/10.18551/rjoas.2018-07.25

\title{
THE LIABILITY OF HIGHWAY PUBLIC TRANSPORTATION LEGALIZATION IN JEMBER REGENCY
}

\author{
Inambala Arum \\ Postgraduate School, Airlangga University, Indonesia \\ E-mail: eliindra10@gmail.com
}

\begin{abstract}
The obstacle of law legalization for public transportation in Jember is caused by the law policing itself, it is the governor regulation number 36 of 2016 which its contents has a clash with home affair ministry regulation number 28 of 2017 which caused in blurred law. The second factor comes from the officers who do not provide scheduled socialization and they do not judge with strict judgement. Thirdly, it is the law awareness from society, people are lazy to commence their administrative law to legalise their vehicle, and the small number of their vehicle which one person only possessed one or two vehicles makes them unwilling to register their vehicle to government. Thus, the law awareness scale among society is still low. The last factor is culture impact which is similar to awareness factor. The culture of people who does not care with the safety, punctuality, and comfort of customers is a character which has been intact among society, this makes them unwilling to register their vehicle.
\end{abstract}

\section{KEY WORDS}

Obligation, public transportation, law, council.

Juridically, the definition of public transportation is stated on article 1 law number 22 of 2009 about Mass Transportation Traffics (known as UULJA). It states that transportation is the displacement of humans or commodities from one place to another which uses vehicle in highway road traffics. Another definition explains that public transportation is the passengers' transportation within renting or paying system. The city public transportation (Bus, minibus, etc), train, water transportation, and planes are all included in mass/public transportation. The transportation used in this study is limited for highway road transportation to fulfil the increasing needs of people on mobility and displacement; it does not matter whether the displacement range is far or close. The public transportation plays important role on controlling traffic jams, fuel/gas saving, and city development and planning.

In order to commence a safety, order, and expeditious mass transportation, it must follow the regulation from the law. One of model to control mass transportation is by applying and registering all public transportation to the state as written on UULLAJ. The driver and the vehicle must be registered according to article 1 act 21 UULLAJ states "the public transportation company is a legal council that provide mass transportation for people and commodities by using motor vehicle". The statement, then, is preceded to government regulation number 74 of 2014 about Road Transportation. According to article 79 government regulation number 74 of 2014, it is clearly stated that the public transportation company must be a legal counsel of Indonesia which follows rules of the constitutions.

By using a legal council on mass transportation, the government will be easier to control the mass transportation procurement. Moreover, the company, within its legal status, must have own workshop. Thus, the safety of vehicles is more guaranteed. Also, the legal company must register their driver, this will reduce the amount of crimes happened among passengers and drivers.

\section{METHODS OF RESEARCH}

This study uses qualitative method as the problem of study is connected with social issues which fundamentally depend on observation. According to Moleong, qualitative 
research is "a research which its purpose is to reveal the phenomenon experienced by the subject of study such as behaviours, perception, motivation, act, and etc, holistically described in the form of words and languages, within most natural special context and by using many natural methods".

In one hand, according to Sugiyono: "Qualitative method is a method which is based on post-positivism philosophy, although for the natural experiment where the researcher is the key instrument of study, the data collection technique uses triangulation. The data analysis is inductive or qualitative, and the result of study focuses on the meaning than generalisation".

Based on the conclusions above, it can be concluded that the qualitative approach is a complete approach to the subject of research where there is an event in which the researcher becomes a key instrument of the research. Then, the result of the approach is described in the form of words written empirical data that have been obtained and in this approach also emphasizes the meaning of generalization.

\section{DISCUSSION OF RESULTS}

There are some problems raised in the obligation to register the public transportation to the state, as follow:

Legal Factor. The constitution regulation is the fundamental law for every law enforcer to do legal action. That is why every law must follow the social movement among societies. As stated by Philip Nonet and Philip Selznick about responsive law, they state that the development of law must be synchronised with the movement of society. Therefore, any laws and regulations will, of course, follow the development, situation, and condition of society. Satjipto Rahardjo states that the law enforcement is started by the time it was approved by constitution. In other words, there is a background of a certain phenomenon that push government to publish regulation in the implementation of law in the form of legislation.

In general, the public policy must be legalised in the form of law, in other hand, law is the product public policy. Thus, the relation between public policy and law could not be separated. The two must get along together within filling each other principal. Theoretically, if a law does not have public policy as its foundation, the law will lose its substantial value vice versa. The public policy without protection of law and constitution will be very weak and easy to be object of violation.

Law publication is one of alternative way to solve a certain problem. Public policy has helped many practice of law to reach such ideal regulation to fulfil the product of law itself. The public policy in question is a legal body policy for public transportation.

The publication of Ministry of Home Affairs regulation number 28 of 2017 replaces the Ministry of Home Affairs regulation number 12 of 2016. The current problem of Ministry of Home Affairs' regulation number 28 of 2017 is that there is no technical regulation from the governor as stated on the previous regulation, Ministry of Home Affairs regulation number 12 of 2016, which is followed by the publication Governor Regulation number 36 of 2016 . As the old law has been cancelled by new one, the Governor Regulation number 36 of 2016 about technical regulation is also cancelled.

It is clearly stated on Ministry of Home Affairs regulation number 28 of 2017: "At the time this Ministerial Regulation comes into force, the stipulation of the Governor Regulation to implement the basis for the imposition of CLA and BBN-KB shall be implemented no later than 30 (thirty) days since the enforcement of this Ministerial Regulation".

Unfortunately, as there is no governor regulation stated in ministerial regulation of home affairs regulation number 28 of 2017, there is a possibility of discretion because there is no governor regulation that exists to be the same as governor rule number 36 of 2016 . This makes uncertainty among law enforcer while practicing state administration especially in Samsat Jember Regency as setting of the study. If the current law is not being amend, there will be no BBN -I or new tariff for public transportation. In the other hand, the state could not use Governor Regulation number 36 of 2016 as it against own policy. 
Law Enforcer Factor. Human resources are one of factor that would determine the successfulness or failure of policy implementation. Edward III stated that "Probably the most essential resources in implementing policy is staff".

According to Soedjono Soekato, several factors that must be applied to achieve proper law enforcement, they are:

- The role model provided by law enforcer;

- Firm manner from law enforcer;

- The synchronisation between current law and technology development;

- Provide proper time for people to understand the new policy;

- Socialisation of regulation obligated among society.

As stated above, from Soekanto explanation, we can conclude that the last factor, socialisation, is a model of which is preventive law enforcement action.

There are several dimension of socialisation policy; they are transmission, clarity, and consistency dimensions. The transmission dimension demands the policy to be delivered not only to the implementers but also to the target of policy itself. , that is why, this communication dimension covers transmission policy which include objectivity clarity within high concentration of visions.

Within consistency dimension, in its practice in Jember Regency, the latest socialisation to inform people about law council policy is commenced by department of transportation and Traffic Police Council in mid 2016 on may until late 2017, the policy of law council has been amend several times since. The latest socialisation is still informed people about the cancelled law, Ministerial of Home Affairs regulation number 26 of 2014 . This law has been replaced by Ministerial of Home Affairs regulation number 12 of 2016 and being replaced again by Ministerial of Home Affairs regulation number 28 of 2017. Thus, we can conclude that the importance and awareness to socialise the current and latest law to society is still low.

That is why, the information received by Organda, as one of legal public transportation company, is not always up to dated. This has been proved by the interview with Umi Indrayanti, she says: "If there is a legal counsel we will be well protected, but we also need a fee for its administration process. And get 30\% incentives if incorporated."

In addition, from the transformation dimension of how a policy should be transformed, according to the author, still does not reach maximum value. This is caused by the media socialization of legal obligations, it does not use banners or through videotron. Socialization used traditional media; so far, they only use the form of talk and involve only Organda. For its effectiveness, members of the Organda also do not necessarily convey the same information to the members below it correctly. So that, the socialization must be put on through banners, videotron, or local radio. So that, clarity of socialization material will be understood clearly and in details for the target group.

Law Awareness Factor. Law awareness, according to Indonesian dictionary, is an individual awareness towards knowledge that a certain action is controlled by law. Law awareness, at some point, is expected to force people to obey and obligate the rule by avoiding any obstacles that would result in law violation. That is why law awareness improvement becomes very important to improve law enforcement.

The result of society who does not possess law awareness is the society who loves to violates their regulation. The violation become worse if it's executed by the law enforcer itself who literary build and publish the policy to society. How could such condition exist within law enforcement and the current state administration?

Law awareness, from language perspective, consist of two words, which the first word is awareness which also means to know and understand. In general, they must understand and know about their regulation/law, according to Ewick and Silbey, they say: "Law Awareness" is the way of how people get to know with their law and its institutions, it is an understanding that provides people with meaning and experience of peoples' action.

According to Ewuick and Silbey, law awareness was formed by action as the result of practice for empirical study. In other word, law awareness is also called "Law as behaviour" 
and not as "law as Norms and principals". Thus, developing law awareness is not such an easy job, because not all people possessed the awareness intact.

Transportation Service council along with Police resort of Jember are the institution who plays important roles in socialising law awareness among society, they have duty to inform and enforce the mass transportation company service to register their company. Unfortunately, there are still many obstacles to achieve the vision. This phenomenon is caused by the majority of the transportation company that is still in form of individual, they are not willing to turn into legal counsel company registered in government within thousands reasons.

From the result of observation, it is revealed the disobedience of people is caused by by several reasons, as follow:

- They are not willing to register their SIUP (Trade Business License), Company Domicile, Taxpayer registration number, Company's Deed;

- The amount of vehicle which is still low, the mostly have or 2 vehicles.

Beside, according Hudan Asrori, the administrator of PKB and BBNKB Police Traffic of Jember, Stated that the low rate of law awareness is caused by:

- The difficulties to register their company in government and the number of vehicle which is low;

- The vehicle owner refuse to possess more burdens by paying tax as their income is still inthe same rate even though the council will be protected by law.

According to Tjatur Sulistianto, the obligation to register the vehicle to become law council has been applied in the regency based on UULLAJ about the mandatory of people to register their mass transportation. But, the law awareness of society is caused by:

- General vehicle owner has low law awareness value within their anomy. It makes them unwilling to register or do some state administration.

- The low awareness of people made the administration of the state not developing which result in complicated process.

- The amount of vehicle which is not being worthy to be registered, one person only possessed one vehicle, that is why, registration becomes not attractive.

According to organda, the disobedience is caused by several factors as follow:

- People assume that the registration is too risky within big and difficult consequences, they think that it is not worthy as they already lent some money to bank and it has no value to be sold in future;

- The cost to register the vehicle is high within complicated process;

- The complicated administrative process.

Government needs some firm action to empower the law enforcement. Aligned with H.C. Kelman, he states that the law obedience consists of:

- The compliance obedience, people are afraid to violate the law because they are frighten of the sanction;

- The obedience identification, people obey the rule as they do not want to break any relationship with their colleagues;

- The internalization obedience, people obey the regulation naturally as they thought that rule is meant to be followed within tits intact intrinsic value.

By basing on the model of legal compliance then with the enforcement of minimal sanctions can provide compliance that is compliance, which is if a person is obedient to a rule just because he is afraid of sanctions.

Edward III (1980) asserted that the success of policy implementation is not only determined by the extent to which the implementers know what to do, but also determined by the will of the policy actors to have a strong disposition of the policy being implemented. This disposition is the willingness, desire, and tendency of policy actors to implement the policy seriously so that what the policy objectives can be realized. This disposition will emerge among policy actors, when it will benefit not only his organization but himself. Ultimately, the intensity of the disposition of the implementers can influence the policy's 
performance. The lack of or limited intensity of this disposition, can lead to the failure of policy implementation.

According to the background of study toward the sanction implementation for the vehicle procurement which does not have legal license is that they need a strong will, desire, and a firm action to implement the sanction directly.

According to the writer's opinion, the sanction applied for the driver who does not register their vehicle is the suspended license. The sanction will be applied as long as they do not register their vehicle. By enforcing the sanction, the government expects that all vehicle owners will be willing to get legal status of their public transportation business. They will not able to operate their business.

For additional policy, to motivate the vehicle owners, transportation State Service of Jember make free of the retribution cost when they want to extend their license to improve and increase the number of legal mass transportation. In one hand, police traffic office, it makes rule for every public transportation that is willing to extend their vehicle registration license, they must be registered as legal mass transportation first to pay the tax.

With the formation of legal entities, the government will more easily monitor the implementation of public transport. In addition, with a legal entity then the legal entity is obliged to have workshop so that more secure vehicle maintenance, which aims to improve the safety of public transport. Plus, legal entities are required to hire drivers according to the prevailing provisions, so criminality by drivers can be minimized.

Cultural factor. Culture awareness is an act to appreciate, understand, and comprehend toward the diversity within the cultures itself. Wunderle stated that there are several steps of culture awareness, as follow:

1) Data and information. Data is the smallest unit of information in cognitive perspective. Data consist of signals or signs which do not go through communication process between code of the systems, or the feeling of environment to detect humans. It is very important to have data and information to improve the communication process.

2) Cultural consideration, after achieving a certain information of a significant culture, we will acquire the understanding towards the culture and factor which becomes the value of the culture. This will be a consideration value about the concept possessed by a certain culture in general to achieve the meaning of cultural code. The cultural consideration will help us to improve and empower the communication and interaction.

3) Cultural knowledge. It is not easy to apply and implement a certain culture even though we already receive the information about the culture. But, the knowledge of a certain culture is a very important asset to face problems in future. The knowledge of other culture is important, but it is also important to learn and understands own culture. That is why, the understanding process of a culture could be maintained through certain trainings. Its purposes are to open the history and understanding of a culture. It includes the major issues of culture such as community, leaders, dynamic, culture's virtue and language competency to understand such culture.

4) Cultural competence. The highest level of culture understanding is cultural competence. The cultural competence is meant to make a decision and cultural intelligence. Cultural competency is the understanding of cultural flexibility. It is very important as it focuses on planning and decision making of a culture on a certain situation. The implication of cultural competency is the intensive understanding of a certain culture.

The knowledge of "what is law" is very important to raise the law awareness among society. It is impossible for a person to obey the rule if they he/she has no idea of what law are. It's very important for people to understand that law was build to protect them from such lawless condition. Beside of the knowledge of law, the understanding of law is as important as knowledge of law. When a person only knows and does not fully understand, then there will be a misunderstanding that resulted in the law not running as it should be. Understanding of the law becomes one thing that must be owned by every individual who run the law. Understanding in this case means the knowledge of each contents in a chapter as well as how the article can be formed and how to run the chapter. Next is awareness of a people's legal obligations to others. It is also important because it will make the law run as it 
should be. When a person knows what he can and should not do to others, and realizes that there will be rewards from everything he does, good or bad, they will automatically have a legal consciousness. Accepting the law, even though people know and understand the law, understand their legal obligations to others, if they do not want to accept the law, then the conscious state of the law will not be realized and the law will not be able to walk as it should. Accepting the law is one sure rule that must be obeyed if the law wants to walk. Getting people to accept the law is not an easy matter, however, regularly taught teachings will have the effect of legal acceptance by the community itself. Thus, if it is analysed from several perspectives above, it is to change the negative culture that has become mindset of society, there are several steps to achieve the law awareness, they are as follow:

1) Action. This is the first and most important way to raise awareness among society. Action could be in a form of punishment if somebody violates the law, and appreciation who obey the law. From that statement, the illegal mass transportation who does not have legal registration must obtain the sanction by cancelling their legal route permission. The sanction come from police traffic office, the vehicle owner must first pay their tax of legal permission to extend their legal vehicle ID. For those who obey the rule, government will appreciate their struggle by decreasing their tax burden of PKB and BBNKB (Tax for motor transportation). The transportation division service could make free the retribution burden for the mass transportation who has registered their number.

2) Education. Everything about the awareness, knowledge, understanding, and law acceptance must be delivered in effective way. Education is one of effective way to deliver the information correctly. Starting from the traffic awareness, this attempt could be implemented by Organda of Jember Regency. Then, it will be delivered to the driver and students even in kinder garden level.

3) Campaign. Campaign is also a good way to introduce law to society. When somebody knows their law, the impact will be whether they receive an appreciation or sanction, thus, the law awareness will be automatically raised within. The campaign should be massive by using banners, videotron, or local radio to socialise the current policy and law to society in meantime.

\section{CONCLUSION AND SUGGESTION}

The obstacle of law legalization for public transportation in Jember is caused by the law policing itself, it is the governor regulation number 36 of 2016 which its contents has a clash with home affair ministry regulation number 28 of 2017 which caused in blurred law. The second factor comes from the officers who do not provide scheduled socialization and they do not judge with strict judgement. Thirdly, it is the law awareness from society, people are lazy to commence their administrative law to legalise their vehicle, the small number of their vehicle which one person only possessed one or two vehicles makes them unwilling to register their vehicle to government. Thus, the law awareness scale among society is still low. The last factor is culture impact which is similar to awareness factor. The culture of people who does not care with the safety, punctuality, and comfort of customers is a character which has been intact among societies; this makes them unwilling to register their vehicle. For various improper reasons and excuses, it is used to maintain a culture of indifference to the mandate of the law regarding legal obligations. So, it takes decisive action, massive campaigns and traffic awareness education to be able to change this negative customs.

Suggestions. Governor as the mandate to commence Governor Regulation Implementation must replace Governor Regulation number 3 of 2016 which is already cancelled by publication of Ministry of Home Affairs regulation number 28 of 2017 . The sanction must be applied firmly by implementation of cancelling their legal route operation and their identity vehicle extension for police traffic office perspective that makes the willing to pay the tax first. In the other hand, transportation Service council must able to set free the charge of retribution of legal route extension and its kir in order to increase the number of legal mass transportation. 


\section{REFERENCES}

1. Ali Achmad, Menguak Teori Hukum (Legal Theory) dan Teori Peradilan (Judicial Prudence) Termasuk Interprestasi Undang-undang, legisprudence, Kencana,2009

2. Joko Widodo, Analisis Kebijakan Publik, Konsep dan Aplikasi Analisis Kebijakan Publik, Bayumedia, Malang, 2010

3. H.Proshansky and Seidberg, Basic Studies in Studies in Social Psychology, Holt Rhinehart \& Witson, New York, 1966

4. Philippe nonet dan Philip Selznick, Hukum Responsif: Pilihan di Masa Transisi, Perkumpulan untuk Pembaharuan Hukum Berbasis Masyarakat dan Ekologis, Jakarta, 2003

5. P. Sujarwoko Warpani, Merencanakan Sistem Pengangkutan, ITB, Bandung, 1990

6. Retnonigsih Anna Suharso, Kamus Besar Bahasa Indonesia, Edisi Lux, Widia Karya Semarang, 2005.

7. Sadjipto Rahardjo, Penegakan Hukum: Suatu Tinjauan Sosiologis. Genta Publishing, Yogyakarta, 2009

8. T. Saiful Bahri, Hessel Nogi S. Tangkilisan, Mira Subandini, Hubungan Hukum dan Kebijakan Publik, Yogyakarta, 2004

9. "Budaya dan Kesadaran Budaya", https://sosiologibudaya.wordpress.com/, Accessed on January $6^{\text {th }} 2017$. 